\title{
Between Genoa and Milan: Giovanni Maria Visconti and His Hagiography of Anton Giulio Brignole Sale (1666)
}

\author{
Pierluigi Giovannucci \\ Dipartimento di Scienze Politiche, Giuridiche e Studi Internazionali, \\ Università di Padova, Padua, Italy \\ pierluigi.giovannucci@unipd.it
}

\begin{abstract}
Giovanni Maria Visconti, member of a prominent family of the Milanese patriciate, had an important career in his order as a teacher and spiritual director, and a valuable role in the internal government of the Society, between Milan and Genoa. After the death of Anton Giulio Brignole Sale, he was charged by his superiors with the task of writing a hagiographic biography of this famous man of letters and politician (son of a Genoese duke) who, after a long cursus honorum in the public offices of his republic and during a period of political crisis of the Genoese state, decided to end his career to become a diocesan priest, and, some years later, a member of the Society of Jesus. The work was published in 1666, with the title Alcune memorie delle virtù del padre Anton Giulio Brignole (Some memoirs of the virtues of Father Anton Giulio Brignole). It is an interesting book especially because the author, while describing Brignole Sale's life and heroic virtues, also explained his transformation from the role of Catholic statesman to the role of religious preacher.
\end{abstract}

\section{Keywords}

Giovanni Maria Visconti - Anton Giulio Brignole Sale - Jesuit hagiography - Republic of Genoa - Gregorio Barbarigo - Theatines

On September 25, 1666, writing from the professed house of San Fedele in Milan to the prominent Venetian cardinal Gregorio Barbarigo (1625-97), bishop of 
Padua, the Jesuit Giovanni Maria Visconti (1612-84) announced that he had just published a bio-hagiographical work about his confrère Anton Giulio Brignole Sale (1605-62; Jesuit from 1652), who had died some years earlier. Visconti had been charged with the task by his superiors, but the extremely concise, even evasive information he provides his correspondent does not allow us to understand the reasons that ultimately lay behind the book. As a matter of fact, describing the circumstances of its composition, he writes as follows:

Father Anton Giulio Brignole of my Society died in Genoa years ago. He was a man whose religious virtues were worthy of being remembered, so I was ordered to gather as much as I could, in order to circulate them as a manuscript among our colleges for spiritual gain. Later [my superiors] deemed it preferable to have them printed in order to avoid the copying labor, and I thought that perhaps Your Excellence might appreciate taking a look at them, particularly since they contain no discourse or thought of the author [i.e., of Visconti], but only the singular deeds of the virtues, of which Your Eminence not only enjoys knowledge, but also practices as well. ${ }^{1}$

The book Visconti mentions in his letter to Barbarigo is titled Alcune memorie delle virtù del padre Anton Giulio Brignole genovese della Compagnia di Gesù (Some memoirs of the virtues of Genoese Father Anton Giulio Brignole of the Society of Jesus). It was printed in Milan in 1666 by the publisher Ludovico Monza (d.1696) and is the subject of the present article. ${ }^{2}$ The main reason for my interest in this work is that the subject of Visconti's biography-notwithstanding the hasty tone of the letter-was a prominent figure in the historical and cultural landscape of mid-seventeenth-century Italian peninsula, especially in his birthplace, the Republic of Genoa, where his political career had an exceptional impact. Furthermore, there is something intriguing about the biography of a high-ranking Genoese "converted" aristocrat such as Brignole,

1 See Pierluigi Giovannucci, "Gesuiti desiderosissimi del suo servitio," in Le relazioni epistolari tra Gregorio Barbarigo e i membri della Compagnia di Gesù, ed. Giovannucci (Padua: Istituto per la storia ecclesiastica padovana, 2016), 153-54.

2 The full title of the little book, in 120 and c.25o pages, is Alcune memorie delle virtù del padre Anton Giulio Brignole genovese della Compagnia di Gesù, raccolte dal p. Gio. Maria Visconte della medesima Compagnia, per consolazione et esempio de' Padri e Fratelli della sua Provincia di Milano (Milan: Lodovico Monza, 1666), hereafter Visconti, Alcune memorie. We know from the date of the imprimatur, released by the provincial of Lombardy, Ignazio Moncada, that Visconti had completed the text by April 1666. 
a biography that was both written by a Milanese Jesuit, Visconti, ${ }^{3}$ who himself descended from an illustrious lineage, and that was submitted by the author to a prominent Venetian prelate of noble origin, Barbarigo, who in his turn had entered the religious order rather late, in his thirties, after having abandoned a short but quite promising political career. ${ }^{4}$

\section{The Historical Figure of Anton Giulio Brignole Sale}

Anton Giulio Brignole Sale was born in Genoa in 1605 and died there in 1662. He belonged to one of the wealthiest and politically most distinguished families of the Genoese nobility of his time: in 1630 his father, Gian Francesco (1582-1637), controlled one of the largest private properties in the republic, and, in 1635-37, was elected to the highest public office of doge. ${ }^{5}$ After completing his education, Anton Giulio devoted himself chiefly to literary work, earning a reputation for his oratorical talent. He composed lyrics in the style of Giovan Battista Marino (1569-1625) and Gabriello Chiabrera (1552-1638), political discourses, satirical verses, as well as gallant and religious narratives, the most successful of which was La vita di Sant'Alessio descritta e arricchita con devoti episodi (The life of St. Alessio, described and enriched with pious episodes), printed in Genoa in 1648. In fact, Brignole is counted among the pre-eminent authors of Italian baroque literature. ${ }^{6}$

3 Born in Milan in 1612, Giovanni Maria Visconti belonged to the ruling elite of the Milanese state. His father, Giovan Battista, was a member of the senate, while his elder brother, the marquis Vercellino Maria, held prominent diplomatic and political-military positions in Spanish Lombardy. Visconti entered the Society in 1626 and held chairs of rhetoric, philosophy, and theology, first in Pavia and then in the Milanese college of Brera, where, in 1662, he was appointed prefect of studies, and then became provincial of Lombardy. He died in 1684. See Giovannucci, "Gesuiti desiderosissimi del suo servitio," xxiii-Xxv.

4 Born in Venice in 1625 to an ancient patrician family, Gregorio Barbarigo pursued a distinguished ecclesiastical career under the patronage of Pope Alexander viI (r.1655-67), becoming bishop of Bergamo in 1657, then cardinal in 166o, and bishop of Padua in 1664 . He died in Padua in 1697 in fame of sanctity; he was beatified in 1761 and canonized by Pope John XXIII (r.1958-63) in 196o. See a short profile of him I published online in Dizionario di eretici, dissidenti e inquisitori nel mondo mediterraneo (Florence: Clori, 2017).

5 On the election of Gian Francesco Brignole to the dogeship, see Carlo Bitossi, Il governo dei Magnifici: Patriziato e politica a Genova fra Cinque e Seicento (Genoa: ECIG, 1990), 230-31.

6 Such is the judgment of Quinto Marini, "'Descrivendo col sacro pennello della lingua': Immagini e parole nella predicazione dell'età barocca; Panegirici in San Siro di Genova," Archivio italiano per la storia della pietà 29 (2016): 304-41, here 319. On Brignole's literary production, see Marco Corradini, "La parabola letteraria di Anton Giulio Brignole Sale," in Corradini, Genova e il barocco: Studi su Angelo Grillo, Ansaldo Cebà, Anton Giulio Brignole 
During the 163 os and 1640s, parallel to his literary endeavors, he also had pursued an outstanding political career, culminating in a long-lasting special legation to the court of Philip IV of Spain (1621-65) in 1644-46, which aimed to resolve some conflicts between the republic and the Spanish ambassador. The positive outcome of his mission ultimately granted Brignole access to the Genoese senate in $1648 .{ }^{7}$

The basic inspiration for Brignole's behavior during this period can be grasped by observing his presence and action in the Genoese Accademia degli Addormentati (Academy of the Sleepers), one of the foremost points of reference for local intellectuals and over which Brignole presided beginning in $1638 .{ }^{8}$ Under his direction, the accademia strove to renovate the structures of the aristocratic republic according to a definite political design, expressed by the so-called Giovani (Youngsters). Their goal was to renew the standing of Genoa as a commercial republic, that is, to make it economically lively and industrious, devoted to productive activities and navigation (instead of being directed by the choices of a narrow, "parasitic" financial oligarchy). In the view of the Youngsters, Genoa was supposed to be a politically and militarily peaceful (though not unarmed) state, and most of all it was not to automatically adopt pro-Spanish positions; in other words, Genoa was to be a political entity firmly attached to its original republican identity, ultimately claiming equality with the major powers on the international stage. ${ }^{9}$

Beyond this political posture, Brignole Sale exhibited, in his academic pursuits as well as in other activities, a deep personal need for ethical-religious renewal, and he conceived of the rhetorical and literary apprenticeship that young nobles undertook upon entering civic life as a preface to their moral education. For instance, in his Tacito abburattato (Tacitus sifted through), he

Sale (Milan: Vita e Pensiero, 1994), 247-308; and Marini, Frati barocchi (Modena: Mucchi, 2000), 19-112.

7 On Brignole's personality and political career, see the entry on him by Gaspare De Caro in Dizionario Biografico degli Italiani [hereafter D BI], 100 vols. (Rome: Istituto dell'Enciclopedia italiana, 1972) 14:277-82 (the date of Brignole's death is wrongly indicated there as 1665). The exact date of his admission to the senate, July 1, 1648, can be found in Bitossi, Il governo dei Magnifici, 27on42.

8 On the Accademia and Brignole's role in it, see Marco Corradini, "Affari, politica ed arti a Genova tra Cinque e Seicento," in Corradini, Genova e il barocco, 3-33, here 17-23, and Marini, Frati barocchi, 42-43.

9 See in particular Bitossi, Il governo dei Magnifici, 214, and Claudio Costantini, La Repubblica di Genova nelletà moderna (Turin: UTET, 1978), especially 286-9o, where the political program of the Giovani is sketched. 
acknowledged an analogy between the academy and the church, according to the schemes of the militant Counter-Reformation religious culture..$^{10}$

From this perspective, it is easier to understand his radical decision to break off a brilliant cursus honorum, just a few months after having joined the senate, that is, between November and December 1648, in order to embrace religious life, initially in the secular clergy, in 1649, and then entering the Society of Jesus in 1652. As the head of a prominent and "demanding" family (his wife Paola Adorno had died at the beginning of 1648 , leaving him with seven sons and daughters), and as a trained and esteemed orator who was experienced in political life yet still relatively young, Brignole may have with good reason to be elected, in time, to the office of doge, as his father had been. Nevertheless, after a disagreement regarding the jurisdictional leanings of most of his colleagues on the occasion of a harsh controversy in fiscal matters between the republic and the city's archbishop, Stefano Durazzo (1594-1667), Brignole suddenly resigned from the senate. His consequent reception of the subdiaconate marked the beginning of a transformation for one of the most prominent figures of the republic, "from ideologue to preacher."11

This outcome, caused by Brignole's choice to side with the church in a conflict between ecclesiastical and secular powers, appears to have been somehow inevitable, given that the republican posture of the Youngsters could hardly agree with his personal, "devout" zeal. ${ }^{12}$ Some years earlier, notwithstanding his political inclination towards the interests of the papacy and the Catholic religion, he had accomplished his diplomatic mission to Madrid with an implicitly anti-Spanish leaning, trying to defend the autonomy and dignity of the republic against the political and military Spanish protectorate; ${ }^{13}$ but now, at the end of the Thirty Years' War (1618-48), after the Spanish defeat at Rocroi, with a strengthened and warlike France aspiring to control the Republic of Genoa, which was a long-standing ally of the Hapsburg powers, such a perspective could be definitively dismissed.

10 See Corradini, Parabola letteraria, 306-7, underscoring the agreement between the antiTacitean stances of Brignole Sale and those of Jesuit authors such as Famiano Strada and Agostino Mascardi.

11 As stated by Costantini, La Repubblica di Genova nell'età moderna, 299.

12 As Elisabetta Graziosi argues, it was not uncommon among the Genoese ruling aristocracy at the time to leave a political career in order to pursue religion: Graziosi, Lancio ed eclissi di una capitale barocca: Genova 1630-166o (Modena: Mucchi, 200o), 125-36.

13 On the issue of anti-Hispanicism in Genoa, see Carlo Bitossi, "Lo strano caso dell'antispagnolismo genovese," in Alle origini di una nazione: Antispagnolismo e identità italiana, ed. Aurelio Musi (Milan: Guerini, 2003), 163-20o. 
In short, to describe Brignole merely as "a man whose religious virtues were worthy of being remembered" (as Visconti wrote to Barbarigo), amounts to an overt exercise of rhetorical dissimulation. But what was it exactly that had to be dissimulated?

\section{Visconti's Bio-Hagiographical Account of Anton Giulio Brignole}

To answer this question, I will examine three different sides of Visconti's bio-hagiography; the three sides serve as useful indications of the biographer's overall attitude towards the character of his subject.

First, it must be underscored that, despite the significance of Brignole Sale's public career and the fact that three-quarters of his life had been spent in the secular world, Visconti relegates this part of Brignole Sale's life to the first, short chapter of the book, a chapter devoted as the title indicates to the Cose memorabili del p. Anton Giulio nella vita secolare sinché si fece ecclesiastico (Memorable things in the secular life of Father Anton Giulio until he became an ecclesiastic), ${ }^{14}$ integrated with a second chapter, specifically devoted to Delle segnalate limosine del $p$. Anton Giulio (The well-known alms of Father Anton Giulio). ${ }^{15}$ Incidentally, it is quite evident that this section of Visconti's book is not only rather general, but also marked by striking misinterpretations, as the following example illustrates.

Among the most recurrent topics in Visconti's book, we find the highlighting Brignole's charity toward the poor, especially the huge alms that earned him, even when he was a layman, the nickname of "God's cashier."16 Moreover, Visconti underscores Brignole's specific resolution to "always answer the poor with docility to 'give alms' to them, even when annoyed by the beggars' insistence."17 Of course, there is no surprise in this, apart from Visconti's mention of the "donation Brignole made to the republic, when he was still a boy, with his father's permission, of a hundred thousand liras to equip a galley" as the starting point of a career in "celebrated" and "extraordinary alms." Actually, Brignole made this donation in 1642, when he was anything but a boy, well after his father's death (which occurred in 1637); in fact, Brignole made this donation when he was the head of his household, and he did so according to a clear political design. Far from being an act of simple "civil generosity," Brignole's

\footnotetext{
14 Visconti, Alcune memorie, 4-14.

15 Visconti, Alcune memorie, 14-29.

16 Visconti, Alcune memorie, 15.

17 Visconti, Alcune memorie, 18.
} 
donation was a strong support to the choice of re-enforcing the Genoese navy and was part of the broader republican political design of the Youngsters. ${ }^{18}$

A second feature of Brignole's bio-hagiography that I would like to consider is the importance the author attaches to the great humility that Brignole showed after entering an ecclesiastical order. ${ }^{19}$ His religious vows had been a resounding act (though not unparalleled in the city), not only because of his high socio-economic and political standing, but also because of his previous, well-known presence in the cultural, intellectual, and even worldly scene. In this perspective, many passages of Visconti's account underscore and describe in edifying tones the gap between Brignole's human and Christian experience before and after having embraced religious life.

For instance, although he was almost an old man when he entered the Society of Jesus, Brignole was extremely compliant with the corrections and suggestions received for "some mistakes, or better, oversights." ${ }^{20} \mathrm{He}$ enjoyed the acquaintance of younger brethren and was seen "becoming younger, and even almost saintly foolish" when talking with them. ${ }^{21}$ Visconti underscores that, while Brignole had previously occupied "his homeland's offices," and was used to "command and rule with his advice not only private, but also public affairs," and although he was "of sharp intelligence, and steadfast in his opinions," once he entered the Society, he became as "highly obedient as every young man and novice," as his superiors testified. ${ }^{22}$ This humble disposition became a habit, shaped by a "simple and low conception" of himself, inducing him to live "with as much submission and seclusion as could have been shown by a poor beggar, hosted in a house for charity." Brignole's humble disposition was exhibited by "his dress, as much as possible more he could do," in "the bearing of his person," and in his "way of communicating."23

In conclusion, Visconti was doing his best to make evident how Brignole's behavior during his religious life was directed toward subverting the etiquette and rituals of precedence among the ruling classes of baroque society,

As demonstrated by Costantini, Repubblica di Genova nell'età moderna, 310-12, showing how this autonomous war fleet was designed to safeguard Genoese maritime interests.

19 The issue is dealt with in depth in the eighth chapter of Visconti's book, 120-49.

20 Visconti, Alcune memorie, 130.

21 Visconti, Alcune memorie, 117.

22 Visconti, Alcune memorie, 223-24.

23 Visconti, Alcune memorie, 148. Visconti adds that, when Brignole as a preacher would visit some city where he had previously forged an acquaintance or an important friendship as a secular, for the sake of modesty he usually "did not accept visits, or show recognition of his old acquaintances" (153). 
according to a model emerging from hagiographical accounts of other servants of God at the time. ${ }^{24}$

Beyond the general attention to the virtue of humility, Visconti specifically focuses his account on Brignole's humility in preaching. ${ }^{25}$ "The religious life of Anton Giulio," he writes, "was spent almost entirely in the apostolic mission of preaching," since his superiors in the Society were at once aware of the "precious talents of nature and grace with which God had endowed him," especially his outstanding rhetorical ability. For this reason, after completing a quick training in theology, he started to preach "and never neglected or stopped doing it anymore, albeit with so little preparation, until he gloriously passed away amidst these apostolic endeavors." 26

According to the biographer, Brignole's oratory was backed by a "most lively talent of natural eloquence" and was invigorated by "a most plentiful, witty, various, imaginative, and solid talk." He "preached with huge firmness in his spirit, with force in his voice, brightness in his face, as if he was wholly and repeatedly attacking his listeners, giving no peace or rest before having carried them away as he wanted." That is why, within a short period of time, he distinguished himself as "one of the most eloquent preachers." ${ }^{27}$

As for his style, his sermons were not stuffed with "empty and useless inventions, and embellishments," neither the "panegyrical nor the solemn among them," but most of them were directed to the point and effective, and he never withdrew from this line "for fear that his audience would melt away," even if the result was overtly unpleasant "to those the Apostle names prurientes auribus." 28

Notwithstanding the success of his preaching activity, we read that Brignole rarely "made mention of it." In fact, "he was never heard to talk about sermons, or eulogies, or other works written or pronounced by him, whether well or badly, neither praising nor blaming, as sometimes can be done to move praise."29 It happened because "he had a very low estimation of his sermons," as shown by how careless he was in writing them down and preserving them. ${ }^{30}$

24 See especially Giulio Sodano, Modelli e selezione del santo moderno: Periferia napoletana e centro romano (Naples: Liguori, 2002), 171-72, who notes how frequently, in early modern canonization processes, the conception of sanctity involves overturning or symbolically reversing social roles.

25 This is the central issue in Visconti's ninth chapter, 149-71.

26 Visconti, Alcune memorie, 149-50.

27 Visconti, Alcune memorie, 81-82.

28 Visconti, Alcune memorie, 83; the scriptural reference is to 2 Timothy 4:3.

29 Visconti, Alcune memorie, $15^{2-53}$.

30 Visconti, Alcune memorie, $150-51$. 
As Visconti underlines, Anton Giulio not only usually refrained from storing his speeches (normally considered "the preacher's treasure") in those "folders designed specifically to preserve them," but he also avoided giving his writings an ultimate stylistic form. He used to write them down not "in neat and whole sheets" but rather "in pieces and rumps" of paper, and even "in someone else's home," that is, "on the letters he received, on their back [...] as well as between their lines," so that his speeches, "with such a contempt of themselves," partook in the meantime "of the most humble poverty of their author." 31

Apart from the hagiographical perspective of Visconti's account, I submit that such an emphasis on modesty and indifference to praise suggests something more than humility. What this something was may be discerned in the special desire with which Anton Giulio is credited, namely, the desire to be exempted from "ostentatious missions," to be "employed in unpretentious places and undertakings," especially in preaching to audiences "from the lowliest classes" rather than in preaching from "ostentatious pulpits of rich places and cities." ${ }^{32}$ The worldly character of early modern religious preaching is well known, ${ }^{33}$ but Brignole's request-which was never satisfied by his superiors - seems to go beyond the simple desire to live out his mission in modest and more secluded contexts; the request rather depends on another peculiar feature of Brignole's conversion, that is, self-criticism of his own oratorical style.

This topic is touched upon in several passages in Visconti's book, starting with an aside at the end of the first chapter where Brignole, criticized for the bombastic style displayed in his exhortations to penitence and charity during his first Lenten sermons in Genoa, publicly rejects the charge that he was trying to "distinguish himself among the other preachers," and claims instead that he only had the aim of helping the poor "with words," at least, given that he could no longer do so with personal alms, since he had given away his wealth. ${ }^{34}$

Further assertions excerpted from the private correspondence of the Genoese Jesuit are even more interesting and revealing. In one case, Anton

31 Visconti, Alcune memorie, 216-17; this passage is quoted also in Marini, Frati barocchi, 84-85.

32 Visconti, Alcune memorie, 167.

33 Visconti, Alcune memorie, 38. Visconti mentions a confrère slightly disapproving the humbleness and shabbiness of Anton Giulio's clothing, all the more noticeable since he was a preacher, that is, a "public person." On this topic, see Michele Miele, "Attese e direttive sulla predicazione in Italia tra Cinquecento e Settecento," in La predicazione in Italia dopo il Concilio di Trento tra Cinquecento e Settecento, ed. Giacomo Martina and Ugo Dovere (Rome: Dehoniane, 1996), 83-109, here 84-87; more broadly, see also Flavio Rurale, Monaci, frati, chierici: Gli ordini religiosi in età moderna (Rome: Carocci, 2008), especially $72-77$.

Visconti, Alcune memorie, 28-29. 
Giulio informs a friend about a series of sermons that "concluded with the spropositi [excesses] of my usual foolishness"; in another, he confesses to "having exaggerated" and having "lacked of judgment" to the point of "deserving to be thrown out of the Society, which I wasn't able to help, but rather only to harm"; and again, he admits to having shut down a Lenten sermon- "loutishly" responding to God's grace that had provided him with enough energy to conclude it—by pronouncing "enormous indecencies." ${ }^{55}$ Against the emphasis on such self-accusations, Visconti feels the need to explain that what Brignole labeled "indecencies" were in reality "neither futilities nor shameful levities," but rather "some personal features, more odd than religious, that had penetrated his style due to his long familiarity with erudite and thoughtful books during his secular life." 36

It must be noted that, in the first part of his account, Visconti had already mentioned that Brignole, though preaching "not for display of eloquence, nor for exhibition of brilliance, [...] but rather for a strong sentiment of Christian piety, and for zeal in gaining fruit in the souls," often enlivened his speeches "not only with gravity, energy, affection, and passion," but also "with notorious examples taken from his own life," not fearing to "castigate himself publicly, with many tears," recanting "the vanity of his conversations" as well as "his printed booklets," and asking "forgiveness from God and men for the bad example he said he had been."37

The issue of Brignole's self-censorship of his "profane" writings recurs several times in Visconti's book. For instance, Visconti reminds his readers that, before entering the Society, Brignole had expressed a "harsh judgment" about "countless" writings that he had "studied and worked on during his secular life so as to reach such a perfection and exquisiteness that his pen had flown on the wings of fame, making him among the most celebrated Italian writers"; instead Brignole labelled those writings "daughters of the sea waves, not of reason."38

35 Visconti, Alcune memorie, $155^{8-59 .}$

36 Visconti, Alcune memorie, 159-6o. According to the author, the term of Brignole's religious apprenticeship had been too short, precluding him from advancing in the study of the church fathers. But it must be remembered that, within the Jesuit training system, especially in the field of rhetoric, the teaching of classical authors was an inescapable point of reference: see Giovanni Baffetti, "Teoria e prassi dell'oratoria sacra nella Compagnia di Gesù," in La predicazione nel Seicento, ed. Maria Luisa Doglio and Carlo Delcorno (Bologna: il Mulino, 2009), 149-68, here 150-51.

37 Visconti, Alcune memorie, 40-41.

38 Visconti, Alcune memorie, 182. The phrase is probably an allusion to Greek mythology: the self-censored works were born out of the sea, like Aphrodite/Venus, goddess of love and passion, instead of from Jupiter's brain, like Athena/Minerva, goddess of wisdom. Marini, 
He also got rid of some manuscripts that he kept at home and considered filled "with vanities and thoughtlessness," "condemning them to the fire," with the exception of some "moral prose" in satirical style and a few verses of a "heroic poem" composed "with honesty," for which he left the choice to his spiritual director. ${ }^{39}$

From this account of Brignole's preaching, there emerges, in my view, an unequivocal general condemnation of secular culture. More specifically, heavy criticism is directed toward baroque conceptismo oratory-including the sacred variety — since it was excessively "inclined toward [...] rhetorical games and the applause of the public." Brignole's criticism is also directed toward a style that was either much too solemn and highbrowed or, the opposite, much too colloquial. ${ }^{40}$

Moreover, it is interesting that such criticism comes directly from his own lips-for instance, in his Satirico innocente (Innocent satirist), published in 1648 - when, before entering religious life, he had inveighed against those preachers who acted as comedians just to please their audience with ever new and brilliant subtleties. ${ }^{41}$ As for him, judging from his only two remaining sacred panegyrics - two eulogies of Andrew Avellino (1521-16o8) and Cajetan of Thiene (1480-1547), delivered at the St. Siro Church in Genoa in 1651 and 1652 , respectively, and printed in the latter year, probably unbeknownst to him-his oratory was based upon biographical-historical data and exhibited a clear and functional style. ${ }^{42}$

Visconti's booklet repeatedly points out the strongly penitential nature of Brignole's sermons, especially those delivered in Genoa, where his position as a "convert" was undoubtedly noticeable. ${ }^{43}$ But the issue of his self-criticism

Frati barocchi, 85, considers it a mere typographical error ("figlie del mare" instead of "figlie del male" [daughters of evil]).

39 Significantly, the spiritual director suggested to Anton Giulio that it was better "to keep those writings, since heathen temples must not be destroyed, but rather dedicated to God." Visconti informs us that after Brignole's death such autograph manuscripts were preserved and kept "in the hands of one who knows what to do with them" (Alcune memorie, 183-84).

40 On the crisis in the teaching of rhetoric and in the sacred oratory of the Society of Jesus during the first half of the seventeenth century, see Mario Zanardi, "Sulla genesi del 'Cannocchiale aristotelico' di E. Tesauro," Studi Secenteschi 23 (1982): 3-61, who reproduces a letter of Superior General Claudio Acquaviva (in office 1581-1615) to the Jesuit provincials, dated May 1613 (37-39) and a second one of Superior General Mutio Vitelleschi (in office 1615-45) to the provincial of Rome, dated April 1617 (39-40), both denouncing the problem.

41 See Marini, Frati barocchi, 87-89, and Marini, "Descrivendo col sacro pennello," 321-22.

42 Marini, Frati barocchi, 64-65.

43 Visconti, Alcune memorie, 34, vividly underscores "the contempt for the world, pomp, vanities, and reputation" that was expressed by the new convert Brignole when he became a preacher. 
was in any case of higher importance for the biographer: while during his secular and early religious career (the preaching at St. Siro predated his entrance to the Society of Jesus) Brignole embraced a "mild-baroque" rhetorical ideal, ${ }^{44}$ after the definitive conversion in 1652 his oratory is imbued with more "disciplined" moral traits, in order to harmonize him with the wider cultural and religious strategy of the Jesuits. ${ }^{45}$

As we have seen, the ecclesiastical career of Anton Giulio Brignole Sale was marked by a double conversion, first from secular to religious life, and then to the Society of Jesus. It is doubtless this second step that attracts more of the biographer's attention - even if it must have been the first step that caused a greater sensation in Genoese society. Although he had resigned his senatorial office after only a few months due to a disagreement with his colleagues over the financial dispute between the republic and Cardinal Durazzo, the archbishop of Genoa, Brignole chose at first not to underscore the openly polemical meaning of his gesture, though that meaning was most likely perceived by the other oligarchs; instead Brignole appealed to a disease (and a quite trivial one at that) in order to justify his resignation. ${ }^{46}$

Within a few weeks, however, this temporary physical indisposition changed into permanent absence, since Brignole resigned irrevocably, taking the minor order of the subdiaconate, the step just below the priestly ordination. As his biographer writes, "apologizing for leaving public affairs, and after having laid down the senatorial robe, he received [...] the ecclesiastical dress, was ordained priest after a short time, and celebrated his first mass with outstanding devotion." ${ }^{27}$ As for the real reason for this choice, Visconti mentions only Brignole's will to "move quickly from worldliness" after having experienced an inner crisis due to a (failed) ambush by some brigands. ${ }^{48}$

In reality, the issue must not have been so easily appeased, especially in the senate. If nothing else, this is what can be deduced from the words of another chronicler, who describes Brignole advocating the church's cause: "During the quarrel between the government and the archbishop, Cardinal Durazzo, Senator Anton Giulio Brignole Sale pleaded in the senate for the cause of the

44 I borrow the definition from Marini, Frati barocchi, 106-9, who contextualizes it in the cultural mood of Genoa during the 1640s.

Baffetti, Teoria e prassi dell'oratoria sacra, 158, labels as a "systematic and consistent cultural project" the rhetorical classicism of the Jesuits, "imposing, or trying to impose itself with quite modern methods and systems."

46 Specifically, a "very considerable cough," as reported by Bitossi, Governo dei Magnifici, $270 \mathrm{n} 43$.

47 Visconti, Alcune memorie, 33-34.

48 Visconti, Alcune memorie, 33. 
church, mentioning many examples of those that had been ruined for their persecution of her." In the meantime, realizing that while he was speaking "some senators were mocking him," Brignole stood up, took off his robe, and abandoned the assembly, saying, "I see that you don't want to come to heaven with me, and I don't want to go to hell with you."49

Now, if Visconti's only purpose was to describe Brignole's outstanding virtue, such a glaring way of leaving secular life would have been an excellent example of his heroic fortitude. But to all appearances, in establishing the historical memory of Brignole's character, including the choice to embrace religious life, which had caused such a sensation in his homeland, Visconti had additional concerns, as can be grasped from his description of the next step in Brignole's conversion, namely, his entrance to the Society of Jesus.

To begin with, it must be observed that Visconti does not devote much space to the activities of Brignole before his entrance to the Society; instead Visconti is content to remind his readers that Brignole's customary occupation was to preach in the urban missions led by the congregation of the Missionari di San Carlo. These missions had been erected by Cardinal Durazzo with the aim of deriving benefit from an "assembly of impassioned men, worthy instruments of his own holy zeal for the instruction of the people and the clergy." Albeit "reluctantly," Anton Giulio soon became its head. ${ }^{50}$

Regardless of this last edifying detail, we can suppose quite confidently that Cardinal Durazzo was happy that one of the most distinguished members of the republican patriciate openly chose to take his side. We have indirect evidence of this approval in the fact that, as Visconti underscores, the archbishop, though "extremely attached to the Society," "deeply regretted" Brignole's decision to join the Jesuits, to the point of overtly expressing his displeasure: "God forgive those who have caused this gentleman to become a regular; they took away the reformer of my clergy."51

In the Genoese context of the time, not a few people probably shared Durazzo's doubts. In my opinion, this is the reason why Visconti reports some very interesting details of Anton Giulio's decision: for instance, that he entered the novitiate without previously informing his friends and relatives, including his aged mother and his own children, with whom he had continued to live

49 Francesco Maria Accinelli, Compendio delle storie di Genova dalla sua fondazione sino all'anno 1776 del prete F. M. Accinelli (Genoa: Angelo Lertora, 1851), 1:116, quoted by Bitossi, Governo dei Magnifici, 270n43.

$50 \quad$ Visconti, Alcune memorie, 43.

51 Visconti, Alcune memorie, 49-50. 
after his vows; ${ }^{52}$ or that he had declined to follow the opinion of his Jesuit confessor, who had been in charge of his soul for many years and had repeatedly tried to dissuade him from joining the Society of Jesus. According to Visconti, Anton Giulio was convinced that such was God's will for him, despite the confessor's misgivings. ${ }^{53}$

With regard to this detail, Visconti includes in his book an interesting text, a note sent by Anton Giulio to his confessor, in which he explained and justified his decision by invoking the intensity of the "calling" of God, "so clear" as to assure him of its genuineness. He acted this way, so wrote Anton Giulio, "without having the leave of Your Paternity" to make a decision that was perhaps wrong "according to the customary way," but which he felt to be inspired by God, "since the brightness and the impulse were extraordinary." Indeed, before making his vow he had "carefully examined everything," feeling himself "more and more pushed." Then he had written the vow on a piece of paper and placed it "under the corporal, when he celebrated Mass," with the aim of taking or renouncing it "according to how I felt inspired by God during the act of communicating"; all during the celebration he seemed to feel "more and more invigorated," and, "while keeping [...] the wafer in the hand," he "inwardly perceived the last push" so that he abandoned himself and his things "in the paternal providence" of God. That being said, Anton Giulio asked for the confessor's approval, yet still affirmed that it seemed impossible to him that "after so many calls made by God, of which the later was ever stronger than the earlier, this one does not really belong to Him, having raised an ardor and a brightness as He had never done before." ${ }^{54}$ After reading this statement, the confessor expressed his astonishment at Anton Giulio's choice, made "without the consultation [...] that was needed in such an affair," deferring any decision to a confidential talk. ${ }^{55}$

In my opinion, the significance of this text lies in its description of a path of spiritual discernment carried out by Brignole in (partial) autonomy; this discernment involved identifying "the indications of the divine Will in the ordering of [one's own] life" through a keen consideration of one's existential condition and experiences, and the relevant deep reflection on them. In other words, vocation is a matter of choice - the specific Ignatian term for this choice is "election"- a choice for what is the most pleasing to God among different

$5^{2}$ Visconti, Alcune memorie, 54.

53 Visconti, Alcune memorie, 51.

54 Visconti, Alcune memorie, 52-53.

55 Visconti, Alcune memorie, 53-54. 
alternatives, each of them liable to change one's life partially or totally. ${ }^{56}$ I detail Brignole's reasoning since it clearly outlines the Jesuit vocation of the Genoese aristocrat as a specifically religious vocation, determined through distinctive spiritual movements, and since certainty regarding the divine character of that vocation is reached by Brignole against the advice of his Jesuit confessor, or regardless of it, on the basis of a typically Jesuit process, namely, spiritual discernment designed for election. In other words, it is as if Visconti describes Anton Giulio Brignole-despite the stunning circumstances of his double conversion - as a Jesuit in pectore well before entering the Society, even against the counsel of his Jesuit spiritual director.

\section{Conclusion}

Finally, I would like to advance some remarks concerning Visconti's biohagiographical narrative, and especially concerning wariness and tentativeness that the author displays in it.

The conversion of Anton Giulio was stunning in mid-seventeenth-century Genoa, and it was undoubtedly perceived as the "conquest" of one of the more esteemed intellectuals of the republic - and, more generally, of the whole Italian peninsula - by the Society of Jesus. Brignole subsequently placed his oratorical talent, and in some respects his political prestige as well, in the service of his order. From this perspective, Brignole's biography could be a good touchstone for a prelate such as Barbarigo, the recipient of Visconti's booklet; despite being much younger than Brignole upon taking vows, Barbarigo had, by 1666 , already enjoyed a prominent career, first as a diocesan bishop, then as a cardinal.

The success of Brignole's conversion-even though it was partly restricted by his mature age at the moment of entering the novitiate, as well as by his outstanding personality and his quite premature death—also had some negative repercussions: his resounding resignation from the senate could not be displayed with too much triumphalism, and even less with a polemical intent toward the Genoese ruling class, since it was important to avoid the risk of reawakening jurisdictionalist debates and anticlerical leanings (maybe the

56 As for the "method of election" in Ignatian spiritual discernment, see Guido Mongini, "Discernimento ed elezione negli Esercizi spirituali di Ignazio di Loyola," Ricerche di storia sociale e religiosa 85-86 (2014): 17-48, 32-41, as well as Mongini, "Devozione e illuminazione: Direzione spirituale e esperienza religiosa negli Esercizi spirituali di Ignazio di Loyola," in Storia della direzione spirituale: L'età moderna, ed. Gabriella Zarri, 3 vols. (Brescia: Morcelliana, 2008), 3:241-88, 266-74. 
same reasons that his confessor had previously declined to support Brignole's desire to enter the Society of Jesus). The same could also be said about leaving his status as a diocesan priest, since his choice for the Society could sound like an indirect "depreciation" of secular priesthood. Most likely, Visconti also had to avoid the further risk of inciting envy from the other religious orders. After all, it cannot be by chance that he underscores the place in which Anton Giulio celebrated his first Mass, namely, in the Cappella del Crocifisso (Chapel of the Crucifix) of the Church of Santa Maria di Castello-the church (with annexed convent) of the Dominican friars, where "the deceased of the House of Brignole" were buried. ${ }^{57}$

A final detail must be noted. In the chapter devoted to the many donations that Anton Giulio made in his bequests, Visconti mentions as "a fair curiosity" that Anton Giulio "didn't leave anything" to the Society. 58 The explanation Visconti gives is, in my view, barely consistent: Anton Giulio was "left deceived," realizing the needs of his own order-and especially the pressing financial needs felt by the colleges of the Milan province-only after having already donated most of his property to his relatives, since his Jesuit brethren had "never requested anything" from him. All he left them was a mere two thousand Roman scudi. ${ }^{59}$

It is hard to believe this explanation. I think that the issue had more to do with the competition between the Jesuits and (in first place) the Theatines, competition that must have occurred when the Genoese aristocrat manifested a desire to enter religious life. Before turning to the Jesuits, Brignole had very likely requested to join the Theatine Regular Clerics of the convent of San Siro in Genoa, meeting with the refusal of Father Stefano Pepe (d.1665). According to the Theatine chronicler Innocenzo Raffaello Savonarola (1680-1748), Pepe replied to Anton Giulio was already living his secular life with "great exemplarity," and Pepe suggested that Anton Giulio not keep "his holy life" "under the bowl," but rather "on a stand"-as in the parable about the light in the Gospel. This counsel had finally induced Anton Giulio to "put himself in the hands of a father of the Society," who accepted him to the order, "maybe not reflecting too much on the public good," as Pepe had done. The Jesuits then received a substantial donation, "which could have been bestowed on us-Savonarola

57 Visconti, Alcune memorie, 34.

$5^{8}$ Visconti, Alcune memorie, 26-27.

59 Visconti, Alcune memorie, 27-28. 
concludes sarcastically - if Father Pepe, without worrying about the greater service of God and the city, had accepted his request." 60

At the time Visconti was writing his book, memory of this incident was distant, and the tensions that had characterized the relationship between Jesuits and Theatines for decades had been diluted. ${ }^{61}$ During the office of the Genoese superior general Gian Paolo Oliva (16oo-81) - his assistant for the Italian provinces, Alessandro Fieschi, was also a Genoese - the Society of Jesus enjoyed a strengthened position in Genoa. Nevertheless, the historical memory of a prominent figure such as Anton Giulio Brignole Sale, and of his complex life choices, must have still been a sensitive matter, to be handled with caution, wariness, and a bit of rhetorical dissimulation.

6o The event (originally recounted in the manuscript Annali della Casa e Chiesa de' Reverendi Padri Chierici Regolari detti Teatini di San Siro) is transcribed in Marini, "Descrivendo col sacro pennello," 335n127.

61 On the role of the Theatines in Genoa and their relationship with the nobility and the other regular orders, especially the Jesuits, see Costanza Longo Timossi, "I teatini e la riforma cattolica nella Repubblica di Genova nella prima metà del Seicento," Regnum Dei 43 (1987): 3-104, here 27-88, and Renato Patrone, "I teatini in San Siro di Genova," Regnum Dei 61 (2005): 83-173. 